\title{
Australian Journal of
}

\section{Volume 35 | Issue 3 | November 2019}

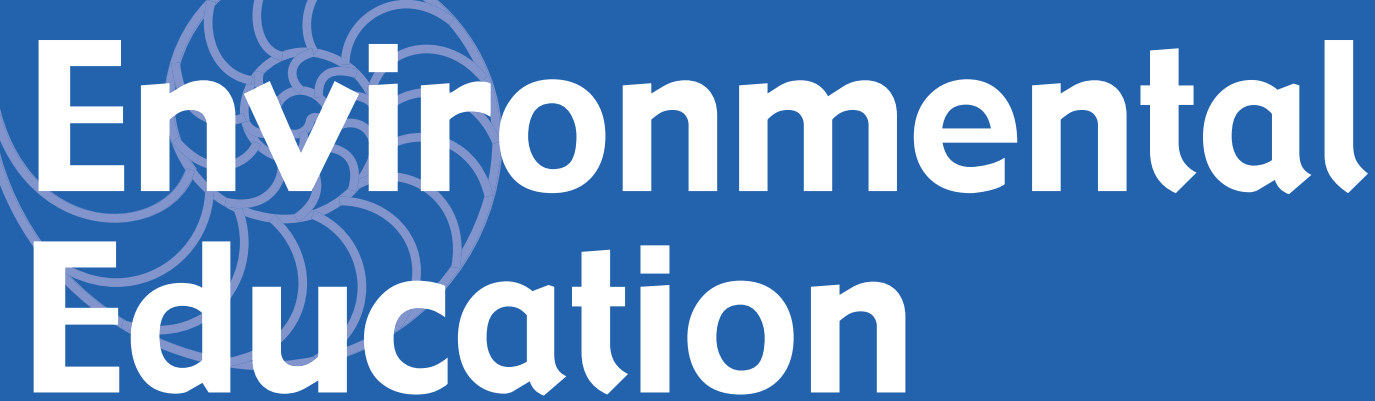

Editors: Amy Cutter-Mackenzie-Knowles and Karen Malone

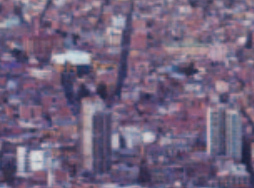

LE.

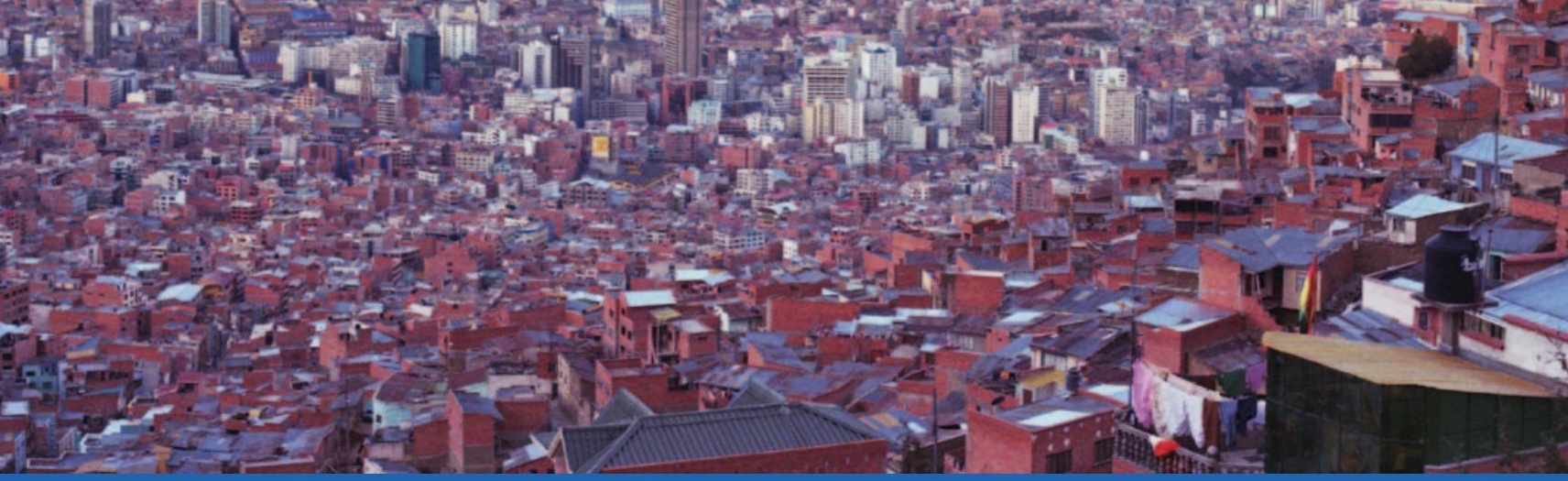


The Australian Journal of Environmental Education is an international refereed journal that publishes papers and reports on all aspects of environmental education. It is the journal of the Australian Association for Environmental Education. It is produced in order to present information and argument that will stimulate debate about educational strategies that enhance the kinds of awareness, understanding and actions that promote environmental and social justice. The journal is addressed to educators working in any educational setting where these matters are centrally or peripherally considered.

\section{EDITORS-IN-CHIEF}

Professor Amy Cutter-Mackenzie-Knowles Southern Cross University, Australia

Professor Karen Malone

Swinburne University of Technology, Australia

\section{ASSOCIATE EDITOR}

Dr Chris Eames

University of Waikato, New Zealand

Dr Peta White

Deakin University

\section{THESIS ABSTRACTS EDITOR}

Dr Sue Elliott

University of New England, Australia

BOOK REVIEW EDITOR

Dr Blanche Verlie

RMIT, Australia

\section{INTERNATIONAL BOARD OF ADVISORY EDITORS}

A/Professor Marcia McKenzie

University of Saskatchewan, Canada

Associate Professor Keith Skamp

Southern Cross University

Professor Julian Agyeman

Tufts University, USA

Mrs Elisabeth Barratt Hacking

University of Bath, United Kingdom

Professor Robert Barratt

University of Gloucestershire, United Kingdom

Dr Kiran Chhokar

Centre for Environment Education, India

Professor Justin Dillon

King's College London, United Kingdom

A/Professor Jo-Anne Ferreira,

Southern Cross University, Australia

(Immediate Past Editor of AJEE)

Professor Annette Gough,

RMIT University, Australia

Professor Paul Hart

University of Regina, Canada

Professor Joe Heimlich

Ohio State University, USA

Professor Heila Lotz-Sisitka

Rhodes University, South Africa

A/Professor Constance Russell,

Lakehead University, Canada

Professor William Scott

University of Bath, United Kingdom

Professor David Selby

Mount St Vincent University, Canada

Professor David Sobel

Antioch College, Keene, USA

Professor Bob Stevenson

James Cook University, Australia

A/Professor Hilary Whitehouse

James Cook University, Australia

A/Professor Sandra Wooltorton

University of Notre Dame, Australia

The Nautilus

\section{SUBSCRIPTION RATES 2019}

This journal is published triannually.

The institutional rates (excluding VAT) are:

Australia

Print and online Electronic Only

N America

370 AUD

348 AUD

UK and ROW

283 USD

268 USD

167 GBP

EU subscribers (outside the UK) who are not registered for VAT should add VAT at their country's rate. VAT registered subscribers should provide their VAT registration number. Prices include delivery by air when appropriate. Japanese prices for institutions are available from Kinokuniya Company Ltd, P.O. Box 55, Chitose, Tokyo 156, Japan.

\section{Orders and subscription enquiries should be addressed to:}

Cambridge University Press, Journals Fulfillment Department, UPH, Shaftesbury Road, Cambridge CB2 8BS, UK

Email: journals@cambridge.org

Orders from N America should be addressed to:

Cambridge University Press, 1 Liberty Plaza, New York, NY 10006, USA

Email: subscriptions_newyork@cambridge.org

The Australian Journal of Environmental Education and all other Cambridge Journals can be found at journals. cambridge.org/

Published by Cambridge University Press. All rights reserved. No part of this publication may be reproduced in any form or by any means, electronic, photocopying or otherwise, without permission in writing from Cambridge University Press.

Permission to copy (for users in the USA) is available from Copyright Clearance Center, www.copyright.com, email: info@copyright.com.

Photo credit: Karen Malone Caption: Witnessing the Anthropocene, La Paz Bolivia.

The Association logo is the nautilus. It is used by the Association to symbolise the "wisdom of the

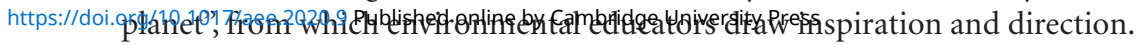




\title{
Australian Journal of Environmental Education
}

\author{
Volume 35(3) 2019
}

\section{Contents}

\section{EDITORIAL}

Environmental education and philosophy in the Anthropocene

David R. Cole and Karen Malone

\section{Articles}

Transcendental Monsters, Animism and the Critique of Hyperobjects

Joff P.N. Bradley.

The Designation of a Deleuzian Philosophy for Environmental Education and Its

Consequences ...

David R. Cole

Red Biocentrism for the Anthropocene

Simon Boxley.

The Ethical and Ecological Limits of Sustainability: A Decolonial Approach to Climate

Change in Higher Education

Sharon Stein .....

Hyperobjects, Media, and Assemblages of Collective Living: Playing With Ontology as Environmental Education

Jesse Bazzul.

Water as method: Explorations of locally situated environmental issues together with preschool children

Teresa Elkin Postila

The application of critical realism as a basis for agency in environmental education:

The case of Roy Bhaskar

Mehri Mirzaei Rafe, Khosrow Bagheri Noaparast, Afzal Sadat Hosseini and Narges Sajadieh

Reflecting on place: environmental education as decolonisation

Simone Thornton, Mary Graham and Gilbert Burgh

Thinking differently: An education for the Anthropocene from Uttarakhand, India

Susan Germein and Neema Vaishnava.

'Attuning-with', affect, and assemblages of relations in a transdisciplinary environmental education

Kathryn Riley and Peta White. 